\title{
Comparison of Growth Performance and Meat Yield of Hilly Chicken under two Feeding Regimens
}

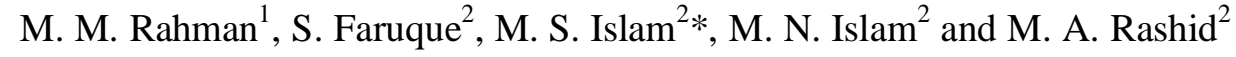 \\ ${ }^{1}$ Biotechnology Division; ${ }^{2}$ Poultry Production Research Division; Bangladesh Livestock Research \\ Institute (BLRI), Savar, Dhaka-1341, Bangladesh \\ *Corresponding author and Email: siraj_blri@yahoo.com
}

Received: 15 April $2013 \quad$ Accepted: 06 December 2013

\begin{abstract}
A total of 108 day-old chicks of hilly chicken were randomly allocated to either pellet form of high protein-energy diet (PHPE) or mash form of low protein-energy diet (MLPE) dietary group having 3 replications in each group. Birds were reared in cages and studied upto 10 weeks of age to compare their growth, feed efficiency and meat production under two feeding regimens. Six birds from each feeding regimen at the age of 8 week were slaughtered to analyze the meat yield characteristics. The live weight of the birds fed PHPE diet was significantly higher (699 \pm 18$)$ than that of MLPE diet (492 $\pm 10)$ at 8 weeks of age. Feed conversion ratio (FCR) was better in PHPE diet $(2.89 \pm 0.03)$ than in MLPE diet (3.22 \pm 0.09$)$. The mortality was similar in birds under two different feeding regimens. Live weight $(\mathrm{g})$ and edible parts weight $(\mathrm{g})$ of birds fed on PHPE diet were significantly higher than that of birds fed on MLPE diet. Dressing percentage did not differ significantly between two feeding regimens. It was concluded that native chicken of hilly areas have the potentiality for meat production and they can utilize high protein energy diet more efficiently.
\end{abstract}

Keywords: Hilly chicken, high protein-energy diet, low protein-energy diet, growth performance, feed conversion ratio, meat yield

\section{Introduction}

Poultry, especially chicken, is the cheapest source of animal protein in the form of eggs and meat throughout the world including Bangladesh (Simon, 2009). It is estimated that there are 188 million chickens including commercial hybrids as well as native chickens in Bangladesh (BBS, 2006). Indigenous chicken of Bangladesh are categorized as non-descriptive Deshi, Naked Neck, Hilly, Aseel and Jungle Fowl (Bhuiyan et al., 2005) based on morphological variation and production performances. Hilly chicken is one of the most important native chickens of hilly areas of Bangladesh which is reared for local consumption of meat and eggs. Meat of hilly chicken has unique taste, delicacy and popularity among consumers in Bangladesh. Local nondescript coloured chicken is a vital source of tasty meat and eggs and more acceptable to rural people (Barua and Howlider, 1990). The local people always try to find the indigenous (deshi) cockerel for its tenderness and special taste (Ahmed and Ali, 2007).

However, the growth pattern and production characteristics of hilly chicken are not well documented. Rahman et al. (2011) found $503 \mathrm{~g}$ 
body weight of hilly Chicken at 8 weeks of age with FCR 2.8. The heavier body size of the hilly chickens compared to other native birds indicates that it can be used as slow growing meat type chicken in Bangladesh. The price of native birds in local market is higher than that of broilers (Islam, 2003) implying that deshi chickens are more demandable compared to exotic commercial table chickens. The information on growth performances of hilly chicken with different regimes of dietary groups are scanty in Bangladesh. Therefore, interest was made to evaluate the growth performances of hilly chicken providing either high protein-energy diet or low protein-energy diet to birds.

Hence, this study was undertaken to: know the growth performances of hilly chicken up to 10 weeks of age under two feeding regimens; determine the feed efficiency; and know the meat yield characteristics of hilly chicken.

\section{Materials and Methods}

A total of 210 hatchings eggs were collected from the matured hilly hens reared at
Naikhongchari Regional Station (NRS) of Bangladesh Livestock Research Institute (BLRI) (80 eggs) and Head Quarter of BLRI (120 eggs). Feeds were formulated by ingredients mentioned in Table 1 that were provided to hilly chickens in both locations during hatching egg collection. The eggs were incubated in Petersime Incubator of BLRI poultry hatchery and 28 and 84 sound chicks were hatched from the flocks at NRS and Head Quarter of BLRI, respectively.

One hundred and eight (108) healthy day-old chicks were identified by wing band and placed randomly in 6 different cages of battery brooders. Two different types of feeds containing $22.23 \% \mathrm{CP}$ and $3153 \mathrm{Kcal} / \mathrm{Kg} \mathrm{ME}$ as pellet form of high protein-energy (PHPE) diet and $19.35 \% \mathrm{CP}$ and $2964 \mathrm{Kcal} / \mathrm{Kg} \mathrm{ME}$ as mash form of low protein-energy (MLPE) diet were randomly allotted in 6 cages. Three replications in each feeding level and 18 chicks in a replication were used in this feeding trial. Feeds were offered to the birds in adlibitum. The ingredients used and nutrient compositions of the diets are shown in Table 1.

Table 1. Ingredients and nutrient composition (\% in DM) of the diets

\begin{tabular}{lll}
\hline Ingredients $(\mathrm{kg} / 100 \mathrm{~kg})$ & PHPE diet & MLPE diet \\
\hline Maize & 55.00 & 51.00 \\
Rice polish & 10.00 & 17.00 \\
Soya bean meal & 29.00 & 25.00 \\
Protein concentrate & 5.00 & 4.00 \\
DCP & 1.25 & 1.25 \\
Lysine & 0.10 & 0.10 \\
Methionine & 0.10 & 0.10 \\
Vitamin-mineral premix & 0.25 & 0.25 \\
Salt & 0.30 & 0.30 \\
Total & 100.00 & 100.00 \\
Kcal/Kg ME & 3153 & 2964 \\
\%CP & 22.23 & 19.35 \\
\hline
\end{tabular}


Fresh drinking water was provided to the birds regularly. The living space in growing cage was 448 sq. cm./bird. A vaccination schedule was followed against New Castle, Gumboro and Fowl Pox diseases. Necessary hygienic measures were ensured for bio-security purposes. Six chickens from each feeding regimen at the age of 8 week were slaughtered to analyze the meat yield characteristics. Data were analyzed by using t-test procedure of SPSS (11.5).

\section{Results and Discussion}

Fertility, hatchability, dead in germ, dead in shell and culled chicks percentage from two sources of hatching eggs are shown in Table 2 . Fertility of hatching eggs was $87.5 \%$ and $67.77 \%$ at BLRI and NRS, respectively. Kirk et al. (1980) found that fertility declined approximately $11 \%$ from 34 to 60 week of the hen age. These findings are higher than the findings of Faruque et al. (2011) who found $46.69 \%$ fertility in hilly chickens. Hatchability percentage on the basis of total egg setting was $31.11 \%$ for the eggs collected from the NRS flocks whereas $70 \%$ was for the eggs from the BLRI flocks which are more than double to NRS flocks of eggs. This result might be attributed to the geographical location, management of birds, storage facility of hatching eggs and breeding by artificial insemination. Studies have shown that hatchability of fertile eggs is influenced by both genetic and environmental factors like storage temperature and humidity, care and handling of eggs, quality of eggs, age and nutrition of layers and season (Olsen and Hyne, 1984). Dead in germ was found double in NRS than BLRI head quarter. The percentage of dead in shell in NRS was three times more than BLRI. The number of chicks culled immediately after hatching of eggs collected from NRS flock was higher than that collected from BLRI flocks.

Table 2. Fertility and hatchability of experimental hilly chicken

\begin{tabular}{|c|c|c|c|}
\hline \multirow{3}{*}{ Parameters $(\%)$} & \multicolumn{2}{|c|}{ Sources of hatching eggs } & \multirow{3}{*}{$\begin{array}{c}\text { Level of } \\
\text { significance }\end{array}$} \\
\hline & BLRI & NRS & \\
\hline & Mean \pm SEM & Mean \pm SEM & \\
\hline Fertility & $87.50 \pm 12.37$ & $67.77 \pm 4.78$ & $*$ \\
\hline Hatchability & $70.00 \pm 9.89$ & $31.11 \pm 2.19$ & $* *$ \\
\hline Dead in Germ & $5.00 \pm 0.71$ & $10.00 \pm 0.71$ & $* *$ \\
\hline Dead in shell & $13.38 \pm 1.88$ & $27.77 \pm 1.95$ & $* *$ \\
\hline Culled chicks & $4.16 \pm 0.59$ & $13.33 \pm 0.94$ & $* *$ \\
\hline
\end{tabular}

** Significantly different at $(P \leq 0.01)$ and *significantly different at $(P \leq 0.05)$.

Table 3. Performances of hilly chickens fed two different diets up to 8 and 10 weeks of age

\begin{tabular}{lllcc}
\hline \multirow{2}{*}{ Parameters } & $\begin{array}{l}\text { Age } \\
\text { (week) }\end{array}$ & PHPE diet & MLPE diet & $\begin{array}{c}\text { Level of } \\
\text { significance }\end{array}$ \\
\cline { 3 - 4 } & & $699 \pm 18$ & $492 \pm 10$ & $* *$ \\
Live weight (g) & 8 & $1802 \pm 31$ & $1483 \pm 21$ & $*$ \\
Feed consumption / bird & & $2.69 \pm 0.04$ & $3.20 \pm 0.04$ & $*$ \\
Feed conversion rate & & 1.85 & 0 & $\mathrm{NS}$ \\
Mortality \% & $937 \pm 25$ & $759 \pm 17$ & $* *$ \\
Live weight (g) & & $2622 \pm 66$ & $2351 \pm 86$ & $*$ \\
Feed consumption/ bird (g) & 10 & $2.89 \pm 0.03$ & $3.22 \pm 0.09$ & $*$ \\
Feed conversion rate & & 1.85 & 1.85 & $\mathrm{NS}$ \\
Mortality \% & & & \\
\hline
\end{tabular}

** Significantly different at $(P \leq 0.01)$, *significantly different at $(P \leq 0.05)$ and NS (Non significant).

$\mathrm{PHPE}=$ Pellet form high protein energy diet, MLPE $=$ Mesh form low protein energy diet. 
The performances of hilly chickens are shown in Table 3. The live weight of birds fed on PHPE diet was significantly higher $(42 \%)$ than birds fed on MLPE diet at 8 weeks of age. Live weight of the birds of MLPE diet group was close to the findings of Rahman et al. (2011) who reported $503 \mathrm{~g}$ live weight for hilly chickens and Faruque et al. (2012) who reported $494 \mathrm{~g}$ for hilly chicken and higher than Faruque et al. (2007) who found $449 \mathrm{~g}$ for hilly chicken. Faruque et al. (2011) observed $373 \mathrm{~g}$ for hilly chickens. However, the live weight of the hilly birds of PHPE diet group was much higher than that the findings of Rahman et al. (2011), Faruque et al. (2012) and Faruque et al. (2011) which indicated that hilly chickens are meat type birds and they responded to higher density of nutrition.

The average feed consumption/bird was significantly higher in PHPE diet group than in MLPE diet group upto 8 and 10 weeks of age. Feed consumption upto 8 weeks of age in PHPE diet group was much higher than the findings of Faruque et al. (2011) who reported $1195 \mathrm{~g}$ for hilly chickens and Faruque et al. (2012) who found $1541 \mathrm{~g}$ in hilly birds. The present findings revealed that pellet form of PHPE diet might have an influence for higher feed consumption over mash form of MLPE diet group. The feed efficiency of hilly chickens under the PHPE diet under any regimen was significantly better than those of MLPE diet group up to 8 and 10 weeks of age. The live weight of hilly chickens fed on PHPE diet was significantly $(P \leq 0.01)$ higher than that of MLPE diet under any group at 10 weeks of age. Live weight of the birds fed on MLPE diet was higher $(8 \%)$ than that reported by Faruque et al. (2012) who reported $703 \mathrm{~g}$ at the same age (10 weeks). Irrespective of age, live weight gain started reducing after attaining $699 \mathrm{~g}$ for PHPE diet and $636 \mathrm{~g}$ for MLPE diet (Table 4). Insufficient, living space (448 sq.cm/bird) in grower cage might be one of the main reasons for this.

However, the live weights of hilly chickens fed on PHPE diet were significantly higher at all ages (1-10 weeks) than those fed on MLPE diet (Table 4). The FCR of the birds of MLPE dietary regimen was better than that reported by Faruque et al. (2011) who reported $3.45 \%$ and Faruque et al. (2012) who reported $3.31 \%$ up to 8 weeks of age. However, the FCR of hilly birds fed on PHPE diet upto 8 weeks and 10 weeks of age were much better than those fed on MLPE diet, and in the findings reported by Faruque et al. (2011, 2012).

Table 4. Weekly live weight (g) of hilly chickens fed on pellet form high protein energy (PHPE) and mesh form low protein energy (MLPE) diets

\begin{tabular}{cllc}
\hline \multirow{2}{*}{ Age (Week) } & \multicolumn{2}{c}{ Mean \pm SEM } & $\begin{array}{c}\text { Level of } \\
\text { Significance }\end{array}$ \\
\cline { 2 - 3 } & PHPE Diet & MLPE Diet & - \\
\hline Day - old & 29 & 29 & $* *$ \\
1 & $54 \pm 0.9$ & $47 \pm 0.6$ & $* *$ \\
2 & $103 \pm 1.8$ & $111 \pm 2.6$ & $* *$ \\
3 & $164 \pm 3.4$ & $162 \pm 3.7$ & $* *$ \\
4 & $241 \pm 5$ & $219 \pm 5$ & $* *$ \\
5 & $328 \pm 6.5$ & $304 \pm 7$ & $* *$ \\
6 & $449 \pm 10$ & $400 \pm 9$ & $* *$ \\
7 & $576 \pm 13$ & $492 \pm 10$ & $* *$ \\
8 & $699 \pm 18$ & $636 \pm 13$ & $* *$ \\
9 & $820 \pm 21$ & $759 \pm 17$ & $* *$ \\
10 & $937 \pm 25$ & & \\
\hline
\end{tabular}

\footnotetext{
** Significantly different at $(P \leq 0.01)$.
} 
Table 5. Meat yield characteristics of hilly chicken fed on pellet form high protein energy (PHPE) and mesh form low protein energy (MLPE) diets

\begin{tabular}{llll}
\hline \multirow{2}{*}{ Parameters } & \multicolumn{2}{c}{ Mean + SEM } & $\begin{array}{c}\text { Level of } \\
\text { Significance }\end{array}$ \\
\cline { 2 - 3 } & PHPE Diet & MLPE Diet & \\
\hline Live weight $(\mathrm{g})$ & $726.67 \pm 45.70$ & $568.66 \pm 23.45$ \\
Edible parts weight $(\mathrm{g})$ & $547.337 \pm 25.86$ & $428.50 \pm 14.56$ & $* *$ \\
Dressing (\%) & $75.35 \pm 1.47$ & $75.38 \pm 1.37$ & $\mathrm{NS}$ \\
$\begin{array}{l}\text { Breast meat weight }(\mathrm{g}) \\
\text { (as \% of live weight) }\end{array}$ & $12.55 \pm 1.81$ & $12.42 \pm 0.48$ & $\mathrm{NS}$ \\
Thigh plus drumstick & $18.98 \pm 0.45$ & $19.67 \pm 0.94$ & $*$ \\
weight (g) (as \% of live & & & \\
weight) & & & \\
\hline
\end{tabular}

** Significantly different at $(P \leq 0.01) *$ significantly different at $(P \leq 0.05)$ and NS (Non significant).

These results indicated that hilly chickens can convert higher protein-energy feed into meat more efficiently, thereby denoting them as meat producing genotype. Mortality did not differ significantly between the birds groups fed higher and lower protein-energy diets during 0-8 and 012 weeks of age.

Meat yield characteristics of hilly chickens fed on different protein-energy levels are shown in Table 5. Live weight $(726.67 \pm 45.70 \mathrm{~g})$ and edible parts weight $(547.337 \pm 25.86 \mathrm{~g})$ of birds under PHPE dietary regimen were significantly higher than that of birds under MLPE dietary regimen. This weights were higher than those reported by Faruque et al. (2007), who reported $554.33 \mathrm{~g}$ live weight of hilly chicken at 8 week of age. Dressing percentage did not differ significantly between two dietary regimens. Breast meat weight as percentage of live weight was not affected by two feeding levels, but thigh plus drumstick weight as percentage of live weight was influenced by different feeding regimens.

\section{Conclusions}

From the results of this study it is revealed that hilly chickens are moderate growing native birds and can utilize higher protein-energy diet more efficiently. It may be suggested that hilly chickens can be improved further for meat production through collection and selective breeding programme.

\section{References}

Ahmed, S. T. and Ali, M. A. 2007. Performance of Synthetic, Desi, Synthetic $\times$ Desi and Synthetic $\times$ Star cross brown chicken at marketing. Proceedings of the $5^{\text {th }}$ International Poultry Show and Seminar, WPSA- Bangladesh Branch, 01-03 March, 2007, 18-25 pp.

Bhuiyan, A. K. F. H., Bhuiyan, M. S. A. and Deb, G. K. 2005. Indigenous chicken genetic resources in Bangladesh: current Status and future outlook. Animal Genetic Resources Information Bulletin, 36:73-84.

BBS. 2006. Bangladesh Bureau of Statistics. Statistical Pocket Book. Dhaka, Bangladesh.

Barua, A. and Howlider, M. A. R. 1990. Prospect of native chickens in Bangladesh, Poultry Advisor, 23: 57-61.

Faruque, S., Sarker, N. R., Islam, M. N. and Sarker, M. S. K. 2007. Performance of native chickens under intensive system. Journal of Bangladesh Agricultural University, 5(2): 283-288.

Faruque, S., Bhuiyan, A. K. F. H., Islam, M. N. and Rahman, M. M. 2011. Breeding for 
the improvement of indigenous chickens of Bangladesh. Paper presented in the Annual Research Review Workshop, Bangladesh Livestock Research Institute, Savar, Dhaka-1341. 24-25, June 2011. 78$91 \mathrm{pp}$.

Faruque, S., Rahman, M. M. and Islam, M. N. 2011. Evaluation of the performance of native chickens and estimation of genetic parameter of body weight. Proceedings of the $7^{\text {th }}$ International Poultry Show and Seminar, World's Poultry Science Association-Bangladesh Branch, 25 - 27, March, 199-206 pp.

Faruque, S., Bhuiyan, A. K. F. H., Bhuiyan, M. S. A., Islam, M. N. and Rahman, M. M. 2012. Conservation and improvement of indigenous chicken. Paper presented in annual research review workshop, Bangladesh Livestock Research Institute, Savar, Dhaka-1341. 24-25, June 2012. 68$69 \mathrm{pp}$.

Hossain, M. M., Howlider, M. A. R. and Hossain, M. J.1991. Growth performance and meat yield of Naked Neck and broiler chicken in a hot humid environment. The Bangladesh Veterian, 8(1-2):4-7.
Islam, M. A. 2003. Comparison of growth rate and meat yield characteristics of cockerels between fayoumi and Sonali under village condition. Ph. D. Thesis, Dept. of Poultry Science, Bangladesh Agricultural University (BAU), Mymensingh.

Kirk, S., Emmanas, G. C., Mcdonald, R. and Arnot, D. 1980. Factors affecting the hatchability of eggs from broiler breeders. British Poultry Science, 21:37-53.

Olsen, M. W. and Hyne, S. K. 1984. The effect of different holding temperatures on the hatchability of hen eggs. Poultry Science, 27:420-426.

Rahman, M. M., Islam, M. M. and Mohanta, U. K. 2011. Conservation and improvement of Hilly chicken. Proceedings of the annual research review workshop. Bangladesh Livestock Research Institute, Dhaka - 1341. 96-99 pp.

Simons, P. C. M. 2009. Commercial egg and poultry meat production and Consumption trade worldwide. Proceedings of the $6^{\text {th }}$ International Poultry Seminar. WPSABangladesh Branch, Dhaka, Bangladesh, $11 \mathrm{pp}$. 